\title{
SelMa - Self-guided Learning in Teaching Mathematics
}

\author{
Wolfgang WEBER \\ Department of Information, Documentation and Communication, State Institute für Schools \\ Paradieser Weg 64, D-59494 Soest, Germany \\ e-mail: wolfgang.weber@mail.lfs.nrw.de
}

Received: March 2004

\begin{abstract}
In the project "Self-guided Learning in Teaching Mathematics - SEC II" (SelMa), five authoring schools are working out scenarios, media and materials for phases of self-guided learning, which will be tested systematically by 10 trial schools with regard to their everyday suitability. In this paper three approaches to such learning arrangements (independent learning centre, jigsaw classroom and learning at stations) are being outlined and relevant experiences are being made available. Learning diaries prove to be useful for the learners' reflection of their learning process. The development as well as the management of such learning arrangements does place new demands on the teachers.
\end{abstract}

Key words: learner centered learning, self-guided learning, classroom arrangements, learning materials, self-assessment.

\section{General Information}

The four-year (1999-2003) pilot project "Self-guided Learning in Teaching Mathematics - SEC II" (SelMa) is funded by the federal government and by the state of North-RhineWestphalia. SelMa is monitored by the LfS (State Institute for Schools). The aim of the pilot project is to show what teaching mathematics at senior high school level can look like if self-guided learning and activities are supported by the use of new media. Special importance is placed on integrating aspects of self-guided learning in everyday teaching.

Learning, mathematics and the use of new media - these are the pillars on which SelMa stands. Special emphasis is placed on the delivery of the new curriculum for mathematics, which focuses upon aspects of self-guided learning and must be integrated in everyday school life. The purpose of SelMa is to give teachers orientation and impulses for their own teaching.

Scenarios and materials for self-guided learning phases in teaching mathematics in SEC III are being developed in five "authoring schools". These learning arrangements are accessible for teachers for trial purposes on the North-Rhine-Westphalian web-site "learn:line" (http: / / www . mathe-selma. de). learn:line provides an information, communication and co-operation environment for this purpose. learn:line encourages the exchange of information and experiences between teachers. 


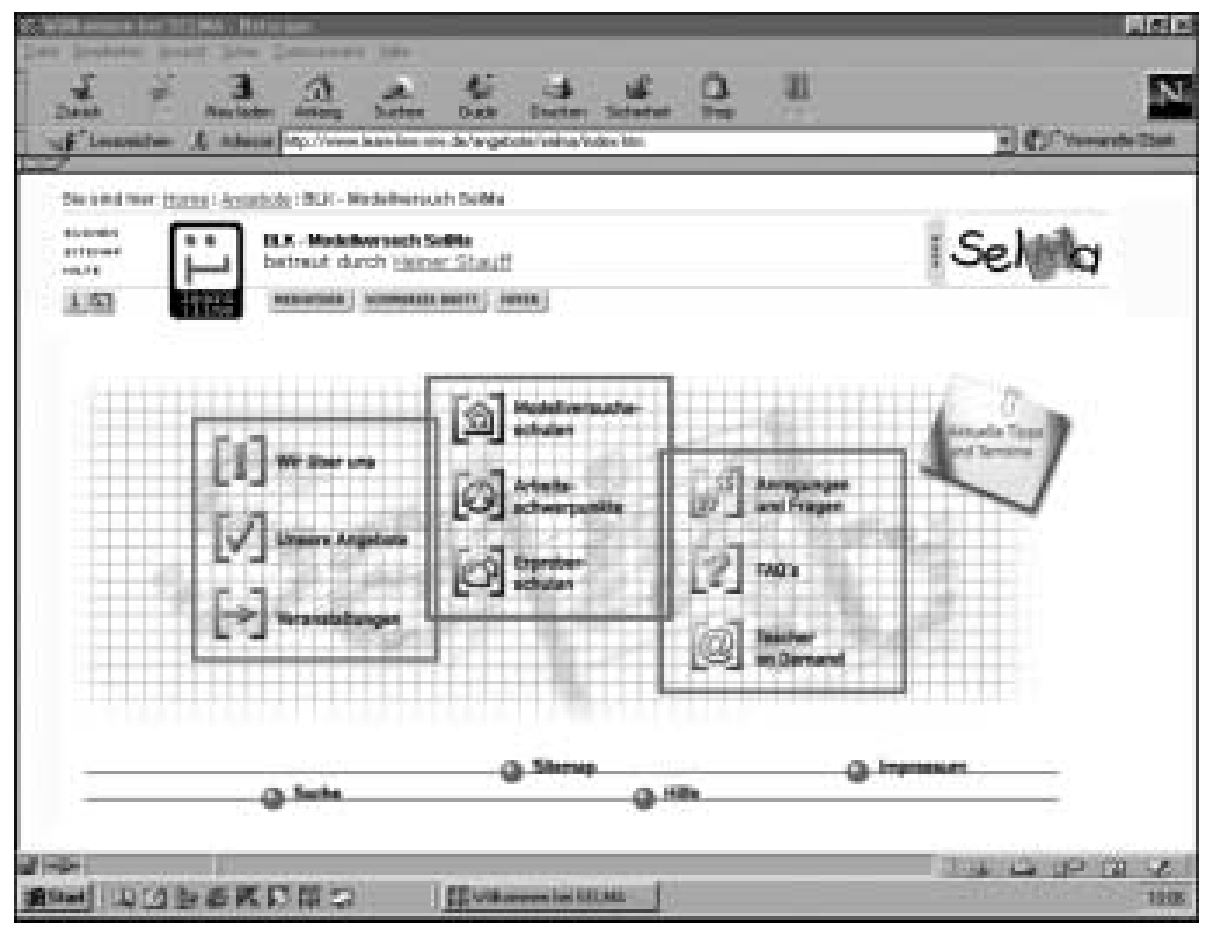

Fig. 1. Home page of the SelMa web-site.

The development of materials by the authoring schools is to take place in an "open workshop", so that other schools can also try out them at an early stage and regularly report on their own experiences. A special role is played by ten "trial schools" which systematically try out and evaluate the materials which have been developed to see whether

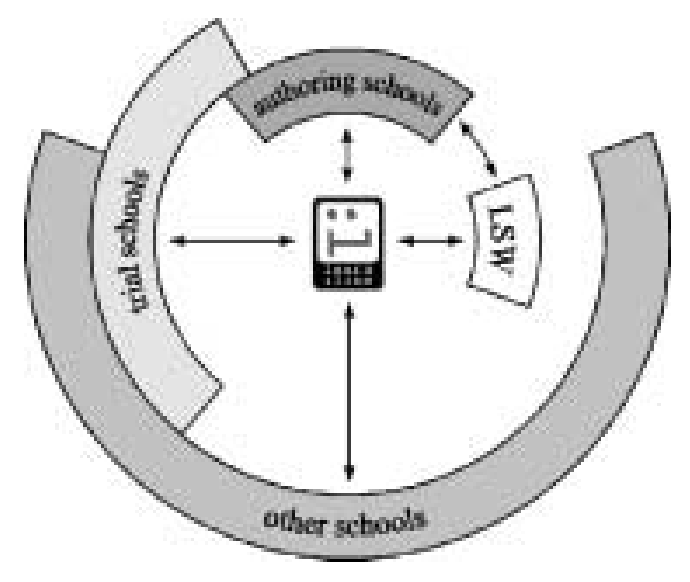

Fig. 2. The SelMa structure. 
they work in everyday usage. Their feedback will be incorporated in the on-going development of materials.

Furthermore, authoring and trial schools are to disseminate their practice so that networks of schools can be created in the different regions and the materials on learn:line can be further developed. In this way the scenarios will be used in an increasing number of schools.

Publishers are to be included at an early stage. This is expected to lead to higherquality (offline and online) media which will support phases of self-guided learning in teaching mathematics. The SelMa project is being evaluated by the Institute for School Development Research, University of Dortmund.

\section{Important Issues}

Based on the focus upon learning, mathematics and use of media, the pilot project addresses various issues. The work of the authoring schools is monitored by academics and experts. Some of the aspects of methodology that are pertinent to learning/self-guided learning are:

- Which topics are suitable for phases of self-guided learning?

- How must the topics be presented?

- What different kinds of support do teachers need?

- What different kinds of support do pupils need?

- How can progress in learning be monitored?

- How do pupils acquire and use their knowledge?

- How can knowledge be consolidated by means of intelligent practice?

- How are media used by pupils?

- How does the use of media improve the quality of learning?

- What off-line and on-line materials must be provided?

- How can communication between the pupils be encouraged?

- What kinds of support are requested?

- What role does a "teacher on demand" play?

- What opportunities for co-operation exist?

These questions show the broad range of issues the SelMa pilot project addresses. The measures taken to qualify teachers so that they can profitably incorporate both the individual learning process and the use of new media in their teaching should not be forgotten, either. 


\section{The Start of SelMa}

At the start of the project the co-operating teachers found themselves facing the following situation: The majority of those learners, with whom the project work is being done, is from secondary level I - mainly familiar with traditional teaching methods focussing on the teacher. With regard to teaching mathematics most of them tend to have little motivation, they are rather passive, receptive and fixated on the reproduction of knowledge or information instead of being geared to own activity. Most lack media and method competence - especially with regard to the new media. For many learners it is a particular novelty to render their own learning process into the subject of contemplation. Based on such a background, independent learning can only be striven for as a fairly long-term target. Many intermediate steps are necessary and it is consequently very time-consuming to develop the necessary competences.

\section{Classroom-Scenarios, Materials-Experiences}

Different scenarios (learning arrangements) and materials for independent learning are being developed and tested in SelMa, whereby each time different facets of independent learning are in the centre of attention. Each and every approach is geared to approaching the ideal of independent learning a bit. Three approaches are to be outlined here.

\subsection{Independent Learning Centre}

Learning in the independent learning centre distinguishes itself quite radically from the other scenarios described herein, insofar as with this approach the learners have no choice but to fend for themselves. In a kind of media centre a variety of traditional and new media are at their disposal - but the teachers, who otherwise accompany the learning processes, are missing.

The work of this SelMa authoring team is closely related to further developments in their school. In an independent learning centre, pupils work on their own, on mathematical topics specified in the curriculum for Years 11 and 12. The material which is prepared for the independent learning centre consists of courses on the one hand and of collections of problems on the other. Graded aids for learning relating to the pupils' existing knowledge provide both food for thought and initial approaches towards solving the problems.

Suggested solutions to the problems allow the learners to check the progress they are making. The computer provides opportunities for simulation and visualisation of mathematics. Pupils normally meet in groups of two or three in the independent learning centre and discuss individual problems. The aim is for the individual pupil to establish as precisely as possible those areas where practice is most necessary.

In the case of the independent learning centre the media used for working - mostly on an individual or partner-oriented basis - by the learners, play an outstanding role. In the end they do primarily work with them over a longer period of time. When designing such media, weighing up now and then openness, that permits independent learning and 
working, against a more compelling leadership that does not leave the learners to cope with their problems single-handed.

Special attendance must therefore be paid to the help systems, which are integrated into the media. It is extremely time and energy consuming to develop such contextsensitive aids, which cover the individual learning situation. This is successfully mastered in the case of well-defined courses, but becomes more and more complex the more open the learning situation is being designed.

With regard to the learners, working in such an independent learning centre demands well-developed competences and places high demands on their self-discipline. The longer the phases of individual learning last, the higher are the demands on planning, structuring and organization of the own learning process. Especially weaker pupils tend to bring in the aids integrated into the media way too early and in a far too intensive manner.

\subsection{Jigsaw Classroom}

Another group of authors tackled in particular the question, how self-directed activity of learners inside the classroom can be specially furthered. While searching for such scenarios, which depart from teacher-focussed teaching in order to reach forms of teaching, where at any given time several or even many learners can be simultaneously active, they came across the so-called jigsaw classroom.

For the jigsaw classroom the teacher divides a larger topic into several (usually 4 6) sub-topics. For each sub-topic he provides materials for self-learning, which are designed in such a way that they can be handled by the learners individually within a given timeframe. With regard to its sequence, the jigsaw classroom is comparatively strictly organized. It is divided into:

introduction, organization of the work;

Phase 1: individual work with the materials for self-study;

Phase 2: experts' round;

Phase 3: exchange round (learning by teaching);

retrospective, reflection of the learning process.

In the phase for individual work, the learners exploit the relevant sub-topic to such an extent, as they are able to handle on an individual basis with the aid of the materials for self-study. Then all those learners, who have tackled the same sub-topic, meet in a group, the so-called experts' round. Here they settle pending questions, discuss their findings and thus jointly become experts for their sub-topic. In this phase they also prepare jointly how they will pass on the newly acquired knowledge to their fellow learners in the next round.

For the following phase the groups will be re-shuffled like in a jigsaw puzzle - so that experts for each and every one of the sub-topics are coming together at one group table. The learners introduce the various sub-topics, discuss them jointly and thus handle the whole of the topic in the group.

The jigsaw classroom is reacted to with a high degree of acceptance both by the learning and the teaching parties. This is probably due to the fact that during the different 

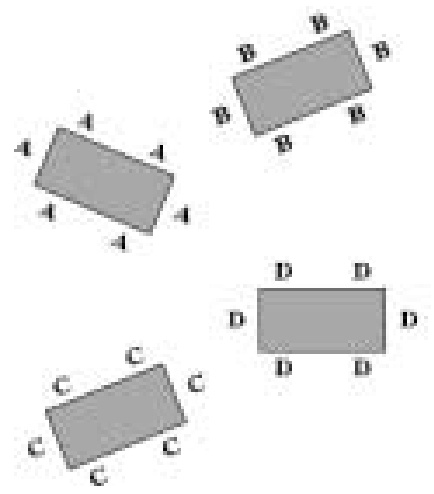

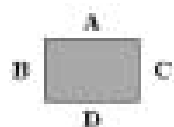

D
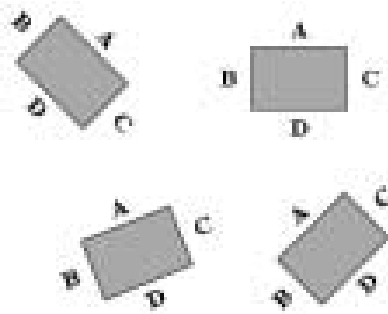
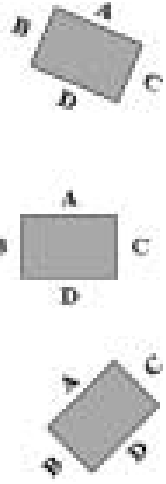

Fig. 3. Phases 2 and 3 of the group jigsaw puzzle.

phases all learners are decisively integrated into the learning processes. Students and teachers experience the exposure to the prevailing topic as being very intensive. The jigsaw classroom supports co-operative work within a group of learners. Quite evidently can the jigsaw classroom strengthen the self-confidence of the otherwise rather quiet or weaker students. The jigsaw classroom may also lead towards a perceptively higher esteem for each other among the learners.

In the case of good preparation, the teacher has completed a "substantial part of his work", when the jigsaw classroom actually begins. The clear structure of the jigsaw classroom enables the teacher to almost completely withdraw from the teaching process while the jigsaw classroom is executed as such. Should the need arise, he is required in the process of group formation, in case or organizational questions and for time control. By withdrawing from the teaching process, a new kind of freedom is created for the teachers. To make use of this freedom in favour of new tasks (e.g. diagnose, consulting) opens up great chances.

\subsection{Learning at Stations}

In this scenario, having pupils study materials at different learning stations particularly supports individual learning. The complete learning circle consists of several (about 20) stations, which are assigned to several thematic areas. The stations are set up in such a way that different background levels of learning, different speeds of learning and working, and different needs in terms of working individually, in pairs or in groups are accommodated. There are compulsory and optional stations.

Thus the learners are enabled - if only within a limited framework - to influence the selection of learning contents. To help pupils find their way, they are given a "docket", which lists all the stations (number; title; topic; compulsory or additional station; individual, pair or group work). Such a "docket" does also contain hints to which aspects might be of significance with regard to the selection decision.

Analogous to the concept of learning at stations the students first of all have to complete their compulsory tasks in the different sections. Due to the optional tasks they them- 
selves may - within a certain framework - influence the choice of topics and also of goals. Especially better performing students are very suitably accommodated by the possibilities offered here. Weaker students, however, are easily and very often being pushed too much by the sheer range of decisions demanded from them. They become rather unsettled and seem to feel that they miss out on important things.

Again with learning at stations the question of making available adequate aids or rather solutions arises. In the opinion of many teachers, access made too easy obviously entices the learners to leave their own path of learning too hastily. They suggest therefore to plan the aids in areas outside of the stations and to preferably have the access monitored by the teacher.

It is remarkable that the stations of the learning circle are rarely adapted by the trial schools in a 1:1 ratio. Teachers are using the possibilities to add to the station circles their own, already proven tasks and to make do without those tasks, which they consider to be less suitable or rather too difficult. It can be observed that in the case of such adaptations the number of options made available to the students is considerably reduced and that thus the degree of reliability is clearly increased. As with the jigsaw classroom most teachers succeed here also to withdraw themselves to quite some extent from the teaching process. Also here the newly emerging freedom could be grabbed to a bigger extent as a new chance.

\section{Learning Diaries}

In all scenarios it is the very cause intended by the teachers that the learners also focus on their own learning process - even if this is quite unusual for most of them. At the beginning this will be done by rather small surveying tasks, which offer the opportunity of discussion. During the course of events more and more aspects are added.

All works towards demonstrating to the learner the advantages of keeping an individual learning diary. Compared with team-related learning diary, this type has demonstrated two strengths. On the one hand, pupils continuously reflect on their progress in terms of the subject matter, and on the other hand, this method allows very personal diary entries about the pupil's progress in learning - provided only the teacher reads the learning diary.

Experiences have shown that the keeping of a learning diary has a permanent and positive effect on the learning process in mathematics at senior high school level if pupils accept this method. The pupils clearly pay more attention to the learning process, try to answer questions immediately (rather than waiting until the last possible minute before the test), and are far more aware of their own strengths and weaknesses when studying mathematics.

The personal learning diary encourages pupils to reflect more on their own learning strategies. Without exception, pupils who had been using this method for some time gradually displayed more stable and better performance in mathematics compared to that at the beginning of the school year. The learning diary supports comprehending and solving mathematical problems. It increases medium and long-term retention and can relatively easily be incorporated in normal everyday teaching. 
But very often it takes the students a lot of will power to approach the teacher as a consultant. Only the strict and clear differentiation between consulting and assessing creates the atmosphere of trust required and enables sustainable behavioural changes. Especially methodical knowledge in the areas of the meta cognition and reflection of learning processes proves to be helpful for the teachers with regard to the stimulation of relevant competences with the students. By way of the learning diaries the teachers additionally gain an important tool for the reflection of their own teaching.

\section{Conclusions}

At the transit point to self-guided learning, the process of learning and the learners themselves are in the very centre of all observation. Which individual dispositions have to be taken into consideration, which previously gained knowledge and which previous experience can be used as a base, which expectations are pupils having with regard to topics and classroom teaching and which goals do they have when they tackle the syllabus - all this is being analyzed to a much greater extent.

It is the teacher's responsibility to create the required basic conditions, to initiate the learning process, to motivate the learners and to consult and assist the learners with regard to their planning and structuring of the learning process, their time-management, their account and back-up of the outcome of their work, their reflection and the evaluation of their own learning processes.

The majority of teachers is only inadequately prepared for this extended role as teachers. During relevant teaching phases they often withdraw themselves too much, which results in the pupils feeling being left alone. In spite of the fact that teachers would now have time for a diagnose of the learning level, which would provide them with important clues with regard to consulting and assisting, they for the most part lack the necessary diagnostic repertoire.

In addition, teachers perceive their deficits with regard to competence in the fields of communication, presentation, methodology and media especially - all of which are important prerequisites for the core competence of designing adequate learning arrangements for phases of self-guided learning.

For this purpose, teachers must know how learners are working with such learning arrangements, in order to gain insight into didactic and methodic design. The compiling of materials for self-guided learning requires that the developers put themselves into the place of the learners and start thinking in the latters' categories of interests, learning prerequisites and expectations. This is the only way to create materials, which at a later stage can be exploited independently by the learners.

During the conceptional stages of such learning arrangements, teachers notice quite often that they actually have only little knowledge of their pupils' learning conditions. If insights into e.g. different types of learners and varying levels of performance, be they low or high, do exist, then still the question remains of how all this has to be considered in the light of compiling materials and learning arrangements. 
Especially in the case of inhomogeneous learning groups, discussions do lead again and again to the questions to what extent help systems are to be integrated into the materials or rather down to which detail they have to be implemented and to what extent they may then support or even hamper self-guided learning.

Phases of self-guided learning are - against popular opinion - mostly more strenuous and labour-intensive than preparing for and conducting of traditional teaching and this is true for both the teacher as well as for the learner. Not least because of this the learners demand again and again to equally allow for phases of traditional teaching.

Also the fear that teachers might become superfluous during phases of self-learning is easily broken up. Teachers are especially during self-learning phases challenged in their capacity as qualified experts and - much more than in traditional teaching - as sympathetic pedagogic consultants and experts for the optimization of individual learning processes.

\section{References}

Baumert, J. et al. (1997). Mathematisch-Naturwissenschaftlicher Unterricht im Internationalen Vergleich. Leske+Budrich Verlag, Opladen.

Büchter, A., A. Preussler, R. Schulz-Zander and M. Heerdegen-Schickhaus (2003). Abschlussbericht der projektspezifischen Evaluation des BLK-Modellversuchs "Selbstlernen in der gymnasialen Oberstufe-Mathematik (SelMa)”. Unpublished Project-Report. Institut für Schulentwicklungsforschung, Dortmund.

Fankhänel, K., and W. Weber (2003). Selbstlernen - Medien - Mathematik. In F. Thissen (Ed.), MultimediaDidaktik in Wirtschaft, Schule und Hochschule. Springer-Verlag, Berlin Heidelberg, pp. 233-248.

Heske, H. (2001). Lerntagebücher. Eine Unterrichtsmethode, die das Selbstlernen im Mathematikunterricht fördert. In Mathematik Lehren, 104, 14-17.

Landesinstitut für Schule und Weiterbildung (2000). Förderung selbständigen Lernens in der gymnasialen Oberstufe. DruckVerlag Kettler, Bönen.

Mandl, H., G. Reinmann-Rothmeier and C. Gräsel (1998). Gutachten zum BLK-Programm: Systematische Einbeziehung von Medien, Informations- und Kommunikationstechnologien (Forschungsbericht $\mathrm{Nr}$ 93). Ludwig-Maximilians-Universität, Lehrstuhl für Empirische Pädagogik und Pädagogische Psychologie, München.

Weber, W. (2003). Professional development needs of teachers managing self-guided learning. In C. Dowling and K. Lai (Eds.), Information and Communication Technology and the Teacher of the Future. Kluwer Academic Publishers. Boston Dordrecht London, pp. 115-124.

W. Weber studied mathematics, biology and computer science. He was teacher at Gymnasium and Gesamtschule. Since 1990 he has been working at the State Institute for Schools in Northrhine-Westfalia, Germany. In this institute he is the head of the Department of Information, Documentation and Communication. His research interests are in the role of information and communication technologies for improving teaching and learning processes. He has organized conferences and promoted projects both at national and international levels. He is project leader of SelMa. 


\section{Savarankiško mokymosi metodo mokant matematikos problematika}

\section{Wolfgang WEBER}

Igyvendinant projektą „Savarankiškas mokymasis mokant matematikos“, sutrumpintai vadinamą SelMa (Self-guided Learning in Teaching Mathematics, penkios mokyklos, žvalgomojo projekto pradininkès, rengè savarankiško mokymo, - kurio tinkamumas kasdieniam mokyklos gyvenimui sistemingai turèsiąs būti išmėgintas dešimtyje bandomujų mokyklu, - skirtingų fazių planus, priemones bei nagrinejjo šiam mokymui reikiamą aplinką.

Straipsnyje nagrinejami trys galimi tokios mokymosi sistemos tipai (nepriklausomas mokymo centras, vadinamoji ,jigsaw“ klase ir mokymasis prie kompiuteriu) bei dalijamasi turima patirtimi.

Pabrežiama mokymosi dienoraščiu svarba ugdant mokymosi proceso refleksiją tarp besimokančiujų. Tokių mokymosi būdụ plètojimas bei taikymas mokytojams kelia naujus reikalavimus. 